\title{
REORIENTASI STRATEGI PEMBANGUNAN BIDANG PEREKONOMIAN DALAM RANGKA PENINGKATAN DAYA BELI MASYARAKAT KABUPATEN KUNINGAN TAHUN 2015
}

\author{
Dewi Fatmasari, M.Si. \\ Enung Nurhayati, SE., Ak., M.Si. \\ Dr. Ayus A. Yusuf, M.Si.
}

\begin{abstract}
abstrak
Penelitian ini bertujuan untuk mengidentifikasi dan menganalisis sektorsektor dalam PDRB, faktor-faktor yang menentukan rendahnya daya beli masyarakat Kabupaten Kuningan dan menjabarkan beberapa skenario rancangan kebijkan pembangunan untuk meningkatkan daya beli masyarakat Kabupaten Kuningan.
\end{abstract}

Metode yang digunakan dalam penelitian ini adalah kajian data sekunder berupa data-data statistik berseri (minimal 5 tahun), data-data hasil pembangunan dan kajian terdahulu yang mendukung; kajian data primer berupa hasil survey, pengamatan, wawancara, observasi, dan teknis pengambilan data lain yang diperlukan; serta perumusan dan formulasi kebijakan melalui analisis berdasarkan gambaran data-data spesifik daerah dan kerangka keilmuan untuk mendapatkan skenario atau grand design strategi pembangunan bidang perekonomian dalam rangka peningkatan daya beli masyarakat Kabupaten Kuningan.

Hasil penelitian menunjukkan bahwa berdasarkan analisis rata-rata kontribusi sektor-sektor dalam PDRB Kabupaten Kuningan, sektor pertanian merupakan sektor dominan, sedangkan sektor perdagangan besar dan eceran, reparasi mobil dan sepeda motor; sektor transportasi dan pergudangan; sektor konstruksi; dan sektor jasa pendidikan merupakan sektor yang berpotensi dominan serta 12 sektor lainnya termasuk kedalam sektor marginal. Rendahnya daya beli masyarakat Kabupaten Kuningan disebabkan masih rendahnya pendapatan perkapita masyarakat Kuningan. Sementara itu kecenderungan hargaharga secara umum (tingkat inflasi) semakin meningkat. Rancangan kebijakan pembangunan untuk meningkatkan daya beli masyarakat di Kabupaten Kuningan, melalui peningkatan konstribusi sektor dominan dan sektor berpotensi dominan,

Kata Kunci : Strategi pembangunan bidang perekonomian dan daya beli masyarakat

\section{PENDAHULUAN}

Visi Rencana Pembangunan Jangka Menengah Daerah (RPJMD) Kabupaten Kuningan 2014-2018 merupakan penjabaran dari Rencana Pembangunan Jangka Panjang (RPJP) 2005-2025 dan merupakan cita-cita masyarakat Kabupaten Kuningan untuk 5 (lima) tahun mendatang yaitu "Kuningan Mandiri, Agamis dan Sejahtera tahun 2018". Untuk melaksanakan visi ini akan diwujudkan melalui pencapaian misi pembangunan Kabupaten Kuningan 2014-2018 yaitu 1) meningkatkan kualitas sumber daya manusia melalui penanaman nilai agama, peningkatan kualitas pendidikan, kesehatan, daya saing dan pengarusutamaan gender dalam kehidupan berbudaya dan harmonis; 2) memantapkan keunggulan kawasan agropolitan, pariwisata daerah, sektor unggulan 
lainnya, peningkatan investasi ramah lingkungan, serta peningkatan sarana dan prasarana daerah; 3) meningkatkan percepatan penanggulangan kemiskinan, melalui pelayanan sosial terpadu dan pemberdayaan masyarakat; 4) memantapkan pelestarian sumber daya alam dan lingkungan hidup dalam kerangka Kabupaten Konservasi dengan menerapkan asas kehidupan berkelanjutan; 5) mewujudkan tata pemerintahan yang baik dan pengembangan kerjasama daerah.

Visi dan misi tersebut dituangkan dalam Peraturan Daerah Kabupaten Kuningan Nomor 9 Tahun 2014 tentang Rencana Pembangunan Jangka Menengah Daerah Kabupaten Kuningan Tahun 2014-2018. Visi Pemerintah Daerah Kabupaten Kuningan mencakup sembilan (9) isu strategis yaitu, 1) peningkatan kualitas dan aksesibilitas pendidikan; 2) peningkatan kualitas pelayanan dan aksesibilitas kesehatan; 3) kualitas infrastruktur daerah; 4) pertumbuhan dan pemerataan ekonomi; 5) penanggulangan kemiskinan dan masalah sosial; 6) peningkatan dan pemantapan ketahanan pangan; 7) reformasi birokrasi; 8) peran gender dalam pembangunan; dan 9) implementasi kebijakan kabupaten konservasi.

Dalam RPJMD tersebut ditetapkan indikator kinerja daerah yang mencakup 3 (tiga) aspek kinerja yaitu: aspek kesejahteraan masyarakat, aspek pelayanan umum; serta aspek daya saing daerah. Aspek kesejahteraan masyarakat dilihat dari PDRB per kapita, Indeks Daya Beli, Laju Pertumbuhan Ekonomi dan Indeks Gini. Aspek Pelayanan umum merupakan segala bentuk pelayanan yang dilaksanakan oleh
Pemerintah Daerah sesuai dengan kewenangan atau urusan yang telah diserahkan baik urusan wajib maupun pilihan. Sedangkan aspek daya saing daerah merupakan indikator yang mengukur kemampuan daerah dalam mencapai pertumbuhan kesejahteraan yang tinggi dan berkelanjutan, dengan indikator yang diukur antara lain: Indeks Pembangunan Manusia, Laju Pertumbuhan Penduduk, Tingkat Kemantapan Jalan, Capaian Luas Kawasan Lindung terhadap Luas Wilayah, Pendapatan Asli Daerah dan Indeks Pendidikan.

RPJMD Kabupaten Kuningan 2014-2018 juga menetapkan target capaian yang akan dicapai pada tahun 2018, salah satunya adalah target pencapaian IPM pada kisaran 75,01 75,91 persen, dengan capaian indeks daya beli pada kisaran 59.75-59.96\%.

Pencapaian target IPM tersebut memerlukan kajian keilmuan yang dapat menjadi dasar pertimbangan dan rujukan bagi pelaksanaan pembangunan daerah. Indeks Pembangunan Manusia (IPM) merupakan indikator komposit yang digunakan untuk mengukur kualitas pembangunan manusia dari aspek pendidikan, kesehatan, dan standar hidup layak. Dengan kata lain, komponen yang membentuk IPM adalah indeks pendidikan, indeks kesehatan, dan indeks daya beli. Dari ketiga komponen IPM, komponen daya beli dianggap sebagai komponen yang mempunyai dimensi ekonomi dan sosial paling luas dalam menggambarkan keberhasilan pembangunan. Kajian ini akan menjawab, bagaimana posisi dan peran strategis peningkatan daya beli masyarakat dalam pencapaian target IPM Kabupaten Kuningan baik jangka menengah maupun jangka panjang sekaligus menjabarkan 
strategi yang dapat diambil untuk peningkatan daya beli tersebut sesuai dengan data, kekhususan daerah dan analisis keilmuan.

Fokus kajian ini berkenaan dengan Reorientasi Strategi Pembangunan Bidang Perekonomian dalam Rangka Peningkatan Daya Beli Masyarakat Kabupaten Kuningan. Dengan demikian arah kajian yaitu berkaitan dengan upaya mencapai indikator kinerja daerah khususnya pada aspek kesejahteraan yang diukur melalui indikator PDRB, Indeks Daya Beli, Laju Pertumbuhan Ekonomi, dan Indeks Gini.

Pencapaian visi 2014-2018 untuk sementara belum optimal, hal ini disebabkan karena kinerja salah satu indeks yang paling menentukan IPM yaitu indeks daya beli justru angkanya tidak menggembirakan. IPM pada periode 2014-2015 meningkat sebesar 0,41 point, dan periode 2013-2014 meningkat sebesar 0,34 point. Sedangkan indeks daya beli periode 2014-2015 meningkat sebesar 0,4 point dan periode 20132014 meningkat sebesar 0,28 point. Namun jika dilihat dari ketiga komponen yang membentuk IPM, indeks daya beli merupakan indeks yang paling rendah dengan peningkatan yang kurang menggembirakan. Hal ini menunjukkan bahwa persoalan daya beli dalam kerangka IPM perlu menjadi fokus perhatian, dengan tetap tidak mengesampingkan indeks pendidikan dan indeks kesehatan sebagai satu kesatuan dalam pembangunan manusia.
Tabel 1.1

Perkembangan Indikator Makro Pembangunan Kabupaten Kuningan Tahun 2013-2015

\begin{tabular}{|c|c|c|c|}
\hline \multirow{2}{*}{ Komponen } & \multicolumn{3}{|c|}{ Tahun } \\
\hline & 2013 & 2014 & 2015 \\
\hline IPM & 73,36 & 73,70 & 74,11 \\
\hline Indeks Pendidikan & 84,67 & 85,19 & 85,40 \\
\hline Angka Melek Huruf (\%) & 98,10 & 98,51 & 98,71 \\
\hline $\begin{array}{l}\text { Rata-Rata Lama Sekolah } \\
\text { (Tahun) }\end{array}$ & 8,67 & 8,78 & 8,82 \\
\hline Indeks Kesehatan & 76,57 & 76,78 & 77,43 \\
\hline $\begin{array}{l}\text { Angka Harapan Hidup } \\
\text { (Tahun) }\end{array}$ & 70,94 & 71,07 & 71,46 \\
\hline Indeks Daya Beli & 58,83 & 59,11 & $\mathbf{5 9 , 5 1}$ \\
\hline $\begin{array}{l}\text { Purchasing } \\
\text { Parity }(\text { Rp) }\end{array}$ & 554.600 & 555.800 & $\mathbf{5 5 7 , 4 9}$ \\
\hline $\begin{array}{l}\text { Laju Pertumbuhan } \\
\text { Penduduk }(\%)\end{array}$ & 0,462 & 0,468 & 0,511 \\
\hline Pengangguran (Jiwa) & $\begin{array}{l}27.734 \\
\text { jiwa }\end{array}$ & $\begin{array}{c}25.909 \\
\text { jiwa }\end{array}$ & $\begin{array}{c}26.039 \\
\text { jiwa }\end{array}$ \\
\hline Persentase Pengangguran & $5,52 \%$ & $5,13 \%$ & $5,47 \%$ \\
\hline $\begin{array}{l}\text { Laju Pertumbuhan } \\
\text { Ekonomi }(\%)\end{array}$ & 6,12 & 6,28 & - \\
\hline $\begin{array}{ll}\text { Jumlah } & \text { Investasi } \\
\text { (Triliyun Rp) } & \end{array}$ & 359,97 & 448,84 & - \\
\hline
\end{tabular}

Sumber: BPS dan Bappeda Kabupaten Kuningan (2015).

Kondisi riil diatas menjadi dasar untuk merumuskan skenario kebijakan pembangunan ekonomi Kabupaten Kuningan kedepan dalam rangka meningkatkan kesejahteraan masyarakat Kabupaten Kuningan melalui peningkatan daya beli masyarakat, dengan terlebih dahulu mengidentifikasi faktor-faktor apa yang menentukan daya beli masyarakat Kabupaten Kuningan, melakukan inventarisasi potensi, pemetaan kondisi dan permasalahanpermasalahan perekonomian yang berkembang di Kabupaten Kuningan.

\section{TINJAUAN PUSTAKA}

Pembangunan Daerah

Pembangunan ekonomi daerah adalah suatu proses di mana pemerintah daerah dan 
masyarakatnya mengelola sumber daya yang ada dan rnembentuk suatu pola kemitraan antara pemerintah daerah dengan sektor swasta untuk menciptakan suatu lapangan kerja baru dan merangsang perkembangan kegiatan ekonomi dalam wilayah tersebut (Arsyad, 2000). Masalah pokok dalam pembangunan daerah adalah terletak pada penekanan terhadap kebijakan-kebijakan pembangunan yang didasarkan pada kekhasan daerah yang bersangkutan (endogenous development) dengan menggunakan potensi sumber daya manusia, kelembagaan, dan sumber daya fisik secara lokal (daerah). Sedangkan pertumbuhan ekonomi diartikan sebagai kenaikan GDP/GNP tanpa memandang apakah kenaikan itu lebih besar atau lebih kecil dari tingkat pertumbuhan penduduk, atau apakah perubahan struktur ekonomi terjadi atau tidak. Namun demikian, pada umumnya para ekonom memberikan pengertian sama untuk kedua istilah tersebut. Mereka mengartikan pertumbuhan atau pembangunan ekonomi sebagai kenaikan GDP/GNP saja. Sedangkan tujuan utama yang ingin dicapai dari pembangunan ekonomi selain menciptakan pertumbuhan yang setinggi -tingginya, harus pula menghapus atau mengurangi tingkat kemiskinan, ketimpangan, dan tingkat pengangguran. Tolak ukur keberhasilan pembangunan dapat dilihat dari pertumbuhan ekonomi, struktur ekonomi, dan semakin kecilnya ketimpangan pendapatan antar penduduk, antar daerah dan antar sektor.

\section{Indikator Pembangunan Ekonomi}

Menurut Mudrajad Kuncoro ada 2 (dua) indikator utama dalam menentukan keberhasilan pembangunan di negara sedang berkembang, yaitu indikator ekonomi dan indikator sosial.

\section{Indikator ekonomi}

a. Laju pertumbuhan ekonomi

b. Gross National Product (GNP)

c. Gross Domestic Product (GDP)

\section{Indikator Sosial}
a. Indikator Sosial Sebagai Alternatif Indikator Pembangunan
b. Indeks Mutu Hidup
c. Human Development Index (HDI)

\section{Strategi Pembangunan Daerah}

Strategi pembangunan daerah merupakan kebijakan-kebijakan yang diambil dalam rangka mengimplementasikan tujuan dan sasaran pembangunan kepala daerah sesuai dengan visi misi yang ditetapkan.

Lincolin Arsyad (2000) secara garis besar menggambarkan strategi pembangunan ekonomi daerah dapat dikelompokkan menjadi 4 yaitu :

a) Strategi pengembangan fisik (lokality or physical development strategy)

b) Strategi pengembangan dunia usaha (business development strategy)

c) Strategi pengembangan sumber daya manusia (human resource development strategy).

d) Strategi pengembangan masyarakat (community based development strategy)

\section{Indeks Pembangunan Manusia}

IPM merupakan suatu indeks komposit yang mencakup tiga bidang pembangunan manusia yang dianggap sangat mendasar yang dilihat dari kualitas fisik dan non fisik penduduk. Kualitas fisik tercermin dari angka harapan hidup, sedangkan kualitas non fisik tercermin dari lamanya ratarata penduduk bersekolah dan angka 
melek huruf, dan mempertimbangkan kemampuan ekonomi yaitu pengeluaran riil per kapita

Perserikatan Bangsa-Bangsa (PBB) menetapkan suatu ukuran standar pembangunan manusia yaitu IPM atau Human Development Index (HDI). Indeks ini dikembangkan pada tahun 1990 oleh pemenang nobel India Amartya Sen dan Mahbub U1 Haq seorang ekonom dari pakistan yang dibantu oleh Gustav Ranis. IPM lebih fokus pada hal-hal yang lebih sensitif dan berguna daripada hanya sekedar pendapatan per kapita untuk melihat kemajuan pembangunan yang selama ini digunakan. IPM dapat mengetahui kondisi pembangunan di daerah dengan alasan:

1) IPM menjadi indikator penting untuk mengukur keberhasilan dalam pembangunan kualitas manusia.

2) IPM menjelaskan tentang bagaimana manusia mempunyai kesempatan untuk mengakses hasil dari proses pembangunan, sebagai bagian dari haknya seperti dalam memperoleh pendapatan, kesehatan, pendidikan, dan kesejahteraan.

3) IPM digunakan sebagai salah satu ukuran kinerja daerah, khususnya dalam hal evaluasi terhadap pembangunan kualitas hidup masyarakat/penduduk.

Meskipun dapat menjadi indikator penting untuk mengukur keberhasilan dalam pembangunan kualitas hidup manusia, tetapi IPM belum tentu mencerminkan kondisi sesungguhnya namun untuk saat ini merupakan satu-satunya indikator yang dapat digunakan untuk mengukur pembangunan kualitas hidup manusia. Konsep IPM menurut UNDP dan Badan Pusat Statistik (BPS) mengacu pada pengukuran capaian pembangunan manusia berbasis sejumlah komponen dasar kualitas hidup, yaitu:

1) Angka harapan hidup untuk mengukur capaian di bidang kesehatan.

2) Angka melek huruf dan rata-rata lama sekolah untuk mengukur capaian di bidang pendidikan.

3) Standar kehidupan yang layak, yang diindikasikan dengan logaritma normal dari produk domestik bruto perkapita penduduk dalam paritas daya beli.

\section{Daya Beli Masyarakat}

Daya beli merupakan kemampuan masyarakat dalam membelanjakan uangnya untuk barang dan jasa. Kemampuan ini sangat dipengaruhi oleh harga-harga riil antar wilayah karena nilai tukar yang digunakan dapat menurunkan atau menaikkan nilai daya beli. Dengan demikian kemampuan daya beli masyarakat antar satu wilayah dengan wilayah lain berbeda. Perbedaan kemampuan daya beli masyarakat antar wilayah masih belum terbanding, untuk itu perlu dibuat standardisasi. Ada beberapa tahap untuk menentukan estimasi daya beli (UNDP, 2001) yakni:

1) Menghitung pengeluaran per kapita dari data modul susenas $[=\mathrm{Y}]$;

2) Menaikkan nilai $Y$ sebesar $20 \%$ [=Y1], karena dari berbagai studi diperkirakan bahwa data dari Susenas cenderung lebih rendah sekitar 20\%;

3) Menghitung nilai riil Y1 dengan mendeflasi $\mathrm{Y} 1$ dengan indeks harga konsumen (CPI) [=Y2];

4) Menghitung nilai daya beliPurchasing Power Parity (PPP)-

5) Membagi Y2 dengan PPP untuk memperoleh nilai rupiah yang 
sudah disetarakan antar daerah [=Y3];

6) Mengurangi nilai Y3 dengan menggunakan formula Atkinson untuk mendapatkan estimasi daya beli [=Y4]. Formula Aktinson yang digunakan untuk menyesuaikan nilai $\mathrm{Y} 3$ adalah:

$$
\begin{aligned}
\mathrm{C}(\mathrm{I}) & =\mathrm{C}(\mathrm{i}) \\
& =\mathrm{Z}+2(\mathrm{C}(\mathrm{i})-\mathrm{Z})(1 / 2 \\
& =\mathrm{Z}+2(\mathrm{Z})(1 / 2)+ \\
& 3(\mathrm{C}(\mathrm{i})-2 \mathrm{Z})(1 / 3) \\
& =\quad \mathrm{Z}+ \\
& (1 / 2)+3(\mathrm{Z})(1 / 3)+4(\mathrm{C}(\mathrm{i}) \\
& 3 \mathrm{Z})(1 / 4)
\end{aligned}
$$

Dimana $\mathrm{C}$ adalah PPP dari nilai riil pengeluaran per kapita dan $\mathrm{Z}$ adalah batas tingkat pengeluaran yang ditetapkan secara arbiter sebesar 549.500 rupiah per kapita per tahun.

Faktor-Faktor yang Menentukan Daya Beli

Berdasarkan pada konsep daya beli terdapat beberapa faktor yang menentukan daya beli diantaranya adalah tingkat pendapatan dan inflasi. Pendapatan yaitu terkait dengan bagaimana kemampuan untuk mendapatkan sejumlah uang, sedangkan inflasi adalah kenaikan harga barang secara umum. Ketika harga-harga barang secara umum naik sedangkan pendapatan masyarakat tetap maka daya beli masyarakat untuk mendapatkan barang dan jasa akan menurun. Dengan keaadaan seperti ini agar tetap tercipta daya beli yang diharapkan adalah bagaimana pendapatan masyarakat dapat meningkat dan harga tetap stabil

\section{Pengukuran Kegiatan Ekonomi}

Kegiatan ekonomi suatu negara dapat diamati melalui dua pendekatan, yaitu pendekatan arus produk dan pendekatan arus pendapatan. Kegiatan ekonomi yang dihitung melalui pendekatan arus produk akan menghasilkan nilai produk nasional atau disebut Gross National Product (GNP). Apabila dihitung melalui pendekatan pendapatan akan menghasilkan nilai/jumlah penghasilan masyarakat atau disebut Gross National Income (GNI). Pendapatan Nasional adalah salah satu indikator kemampuan dan kualitas sumber daya suatu Negara. Semakin baik dan berkualitas sumber daya suatu Negara maka semakin besar pendapatan nasionalnya.

Ada tiga metode/pendekatan (approach) dalam menghitung pendapatan nasional antara lain:

\section{A. Metode produksi/production approach.}

Metode produksi digunakan untuk menentukan pendapatan nasional dengan cara menjumlahkan nilai produksi yang dihasilkan oleh sektorsektor produksi. Sektor yang dimaksud adalah:

1) Pertanian / Agriculture

2) Pertambangan dan penggalian/ Minning and Quarrying

3) Industri pengolahan/ Manufacturing Industries

4) Listrik, Gas, dan air bersih/ Electric, Gas, and Water supply

5) Bangunan/ Construction

6) Perdagangan, Restoran dan Hotel/ Trade, Restaurant and Hotel

7) Pengangkutanan dan komunikasi/ Transportation and Communication

8) Keuangan, Persewaan bangunan dan Jasa perusahaan/ Finance, Rent of Building and Bussines service

9) Jasa- jasa/ Service berikut:

Persamaannya adalah sebagai

$$
\begin{gathered}
\mathbf{Y}=\sum \text { Pqn.Qin } \\
\mathbf{Y}= \\
\begin{array}{c}
\text { Pq1.Q1+Pq2.Q2+Pq3.Q3... }+ \text { Pq9.Q } \\
\text { Pqn }=\text { harga dari sektor } \mathrm{n}
\end{array}
\end{gathered}
$$


Q1.Q2.Q3 = jumlah produk dari masing-masing sektor.

Untuk menghindari perhitungan ganda dalam metode ini, maka dilakukan hanya menjumlahkan nilai tambah dari masing-masing sektor produksi /menjumlahkan nilai akhir dari hasil produksi, sebagai berikut:

$$
\begin{aligned}
& \mathbf{Y}=\sum \mathbf{N T B} \\
& \mathbf{9}=\mathrm{NTB}_{1}+\mathrm{NTB}_{2}+\mathrm{NTB}_{3}+\ldots \mathbf{N}
\end{aligned}
$$

TB9 \{Produk Domestik Brutto $(\mathrm{PDB})=\mathrm{GDP}\}$

\section{B. Metode pendapatan/income approach.}

Metode ini menjumlahkan semua pendapatan dari faktor-faktor dalam perekonomian yaitu manusia (TK), modal, tanah, skill. Tenaga keja menghasilkan upah (Wages $=\mathrm{W}$ ), Modal menghasilkan bunga (Interest $=\mathrm{I}$ ), tanah menghasilkan sewa(Rent $=$ R),dan Skill menghasilkan profit $($ Profit $=\mathrm{P})$, maka dapat ditulis:

$$
\mathbf{Y}=\mathbf{Y}_{\mathbf{W}}+\mathbf{Y}_{\mathbf{I}}+\mathbf{Y}_{\mathbf{R}}+\mathbf{Y}_{\mathbf{P}}
$$

Hasil perhitungan pendapatan sering dinamakan sebagai pendapatan Nasional $=P N($ Nasional Income $=N I)$

\section{C.Metode pengeluaran/expenditure} approach.

Metode ini menghitung pendapatan nasional dengan cara menjumlahkan pengeluaran baik dilakukan oleh rumah tangga konsumen (C), rumah tangga swasta/produsen (I) rumah tangga pemerintah (G) dan Export netto (XM). Persamaannya sebagai berikut:

$$
Y=A E=C+I+G+(X-M)
$$$$
, \rightarrow A E=\text { Aggregate Expenditure }
$$

Hasil perhitungan dengan metode pengeluaran sering dinamakan sebagai Produk Nasional Bruto $=P N B \quad($ Gross National Product $=$ GNP)

\section{Perubahan Struktur Ekonomi}

Pertumbuhan ekonomi tidak terlepas dari terjadinya perubahan struktur ekonomi. Pertumbuhan ekonomi umumnya adalah merupakan seluruh usaha yang dilakukan untuk memperluas produksi dan meningkatkan pendapatan, sedangkan perubahan struktur ekonomi merupakan perubahan komposisi sektoral terhadap pembentukan Produk Domestik Bruto di suatu negara atau daerah.

Teori pertumbuhan regional dari hasil pengamatan empirik Clark dan Fisher (1940), berpendapat bahwa kenaikan pendapatan perkapita di berbagai daerah pada berbagai waktu pada umumnya diikuti dengan pergeseran dan peralihan permintaan secara berangsur-angsur dari sektor produksi primer ke sektor produksi sekunder dan tersier. Hal ini pada gilirannya akan mengakibatkan perubahan dalam struktur produksi, melalui pergeseran kesempatan kerja dan alokasi dana. Tingkat produktivitas yang berbeda pada berbagai sektor ekonomi, dan terdapatnya laju pertumbuhan yang berbeda diantara sektor-sektor menyebabkan terjadinya pergeseranpergeseran di antara peran masingmasing sektor terhadap komposisi produk nasional. Hasil produksi sektor pertanian secara absolut dapat terus bertambah, akan tetapi kontribusi produksi pertanian terhadap produk nasional secara relatif menurun. Kecenderungan tersebut diikuti oleh meningkatnya produksi sektor industri manufaktur dan sektor jasa.

Perubahan struktural juga dapat dilihat dari sudut pergeseran kesempatan kerja, yang dilihat dari jumlah angkatan kerja yang bekerja pada masing-masing sektor produksi. Clark dalam penelitiannya mengemukakan, bahwa terdapat hubungan yang erat antara perubahan 
struktur produksi dengan struktur kesempatan kerja menurut sektor. Penyerapan tenaga kerja yang tinggi dapat dicapai dengan : pertama, peningkatan produktivitas tenaga kerja di setiap sektor; kedua, bergesernya tenaga kerja dari sektor produktivitas yang lebih rendah ke sektor dengan produktivitas yang lebih tinggi.

Dengan demikian dapat disimpulkan bahwa penurunan peranan sektor pertanian dalam menciptakan produksi nasional diimbangi dengan kenaikan yang hampir sama besarnya pada sektor industri. Perubahan struktur ekonomi yang digambarkan oleh Kuznets, menunjukkan bahwa sektor pertanian mengalami perkembangan produksi yang lebih lamban dibandingkan dengan laju pertumbuhan sektor industri. Tidak terdapatnya perubahan kontribusi sektor jasa dalam produksi nasional, yang berarti perkembangan sektor jasa adalah sama dengan tingkat pertumbuhan produksi nasional.

\section{METODE KAJIAN}

\section{Pendekatan dan Metode}

Kegiatan Penyusunan Dokumen Reorientasi Strategi Pembangunan Bidang Perekonomian dalam rangka Peningkatan Daya Beli Masyarakat Kabupaten Kuningan menggunakan pendekatan sektor-sektor perekonomian dominan yaitu kegiatan perekonomian yang menyumbang PDRB tertinggi, bersifat masif dan mencakup mata pencaharian penduduk dalam jumlah yang signifikan. Pertimbangan lain untuk sektor perekonomian dominan atau berpotensi dominan adalah gambaran potensi sumber daya alam, kemajuan teknologi pemanfaatan potensi SDA dan peningkatan kualitas SDM dalam mengeplorasi potensi ekonomi daerah. Metode yang digunakan meliputi:

1. Kajian data sekunder berupa datadata statistik berseri (minimal 5 tahun), data-data hasil pembangunan dan kajian terdahulu yang mendukung;

2. Kajian data primer berupa hasil survey, pengamatan, wawancara, observasi, dan teknis pengambilan data lain yang diperlukan;

3. Perumusan dan formulasi kebijakan melalui analisis berdasarkan gambaran data-data spesifik daerah dan kerangka keilmuan untuk mendapatkan skenario atau grand design strategi pembangunan bidang perekonomian dalam rangka peningkatan daya beli masyarakat Kabupaten Kuningan.

\section{Lokasi Penelitian}

Penelitian ini mengambil lokasi penelitian di Kabupaten Kuningan dengan responden pelaku usaha di sektor dominan, potensial dan marginal. Selain pelaku usaha, kegiatan pengumpulan data primer juga dilakukan dengan pemangku kebijakan yang berhubungan erat dengan kebijakan ekonomi di Kabupaten Kuningan yaitu: Bupati, DPRD, Dinas Perindustrian dan Perdagangan, Dinas Koperasi dan UKM, Badan Pelayanan Perijinan Terpadu dan Penanaman Modal, Dinas Pendapatan Daerah, Badan Perencanaan Pembangunan Daearah, Dinas Pertanian Perikanan dan Peternakan, Badan Ketahanan Pangan dan Pelaksana Penyuluhan, Dinas Kehutanan dan Perkebunana, Dinas Sosial dan Tenaga Kerja, dan Dinas Pariwisata dan Kebudayaan. 


\section{Jenis Data Penelitian}

Jenis data penelitian terdiri data primer dan data sekunder. Data primer dalam penelitian ini diperoleh melalui kegiatan survei, metode untuk pengumpulan data primer yang mendasarkan pada komunikasi dengan perwakilan sampel secara individu (Wibisono: 2013, 113). Data primer dikumpulkan dengan teknik wawancara dan kuesioner yang diajukan kepada responden. Dan data Sekunder merupakan data primer yang telah diolah lebih lanjut dan disajikan baik oleh pihak pengumpul data atau pihak lain.

\section{Teknik Pengumpulan Data}

Teknik pengumpulan data dilakukan melalui beberapa kegiatan:

1. Wawancara/interview dengan pemangku kebijakan yang berhubungan erat dengan kebijakan ekonomi di Kabupaten Kuningan yaitu: Bupati, DPRD, Dinas Perindustrian dan Perdagangan, Dinas Koperasi dan UKM, Badan Pelayanan Perijinan Terpadu dan Penanaman Modal, Dinas Pendapatan Daerah, Badan Perencanaan Pembangunan Daearah, Dinas Pertanian Perikanan dan Peternakan, Badan Ketahanan Pangan dan Pelaksana Penyuluhan, Dinas Kehutanan dan Perkebunana, Dinas Sosial dan Tenaga Kerja, dan Dinas Pariwisata dan Kebudayaan.

2. Kuesioner yang disebarkan kepada para pelaku usaha diberbagai sektor perekonomian.

3. Studi dokumentasi yaitu teknik pengumpulan data melalui studi kepustakaan dan browsing di internet.

4. Focus Group Discussion melalui diskusi interaktif yang melibatkan para stakeholder.

\section{Jenis Penelitian}

Penelitian ini menggunakan pendekatan kuantitatif selanjutnya disebut penelitian kuantitatif-satu bentuk penelitian ilmiah yang mengkaji satu permasalahan dari suatu fenomena, serta melihat kemungkinan kaitan atau hubunganhubungannya antar variabel dalam permasalahan yang ditetapkan (Indrawan dan Yuniawati, 2014: 51).

Berdasarkan tingkat eksplanasi, penelitian ini termasuk penelitian deskriptif yaitu penelitian yang bertujuan untuk mengangkat fakta keadaan, variabel dan fenomenafenomena yang terjadi saat sekarang (ketika penelitian berlangsung) dan menyajikannya apa adanya (Wirartha, 2006:155).

\section{Populasi, Sampel, Dan Teknik Pengambilan Sampel}

Menurut Sugiyono (2011) Populasi adalah wilayah generalisasi yang terdiri atas obyek/subyek yang mempunyai kualitas dan karakteristik tertentu yang ditetapkan oleh peneliti untuk dipelajari dan kemudian ditarik kesimpulannya. Populasi dalam penelitian ini adalah Pelaku usaha di berbagai sektor perekonomian di Kabupaten Kuningan yaitu sebanyak 1.244 pelaku usaha. Sampel adalah sebagian atau wakil dari populasi yang akan diteliti (Arikunto,2006). Sampel adalah bagian yang diambil dari keseluruhan obyek yang diteliti dan dianggap mewakili seluruh populasi (Notoatmodjo, 2010).

Untuk menentukan ukuran sampel digunakan Rumus Slovin dengan tingkat kesalahan sebesar 5\%,

$$
n=\frac{N}{1+N(e)^{2}}
$$

Keterangan:

$\mathrm{n}=$ Ukuran sampel

$\mathrm{N}=$ Ukuran populasi 
$\mathrm{e}=$ Tingkat kesalahan $(5 \%)$ sehingga ukuran sampel yang diperoleh yaitu:

$$
\begin{aligned}
& n=\frac{1.244}{1+1.244(0.05)^{2}} \\
& n=302,68 \\
& n=303 \text { (dibulatkan) }
\end{aligned}
$$

Teknik Sampling yang digunakan dalam penelitian ini adalah Proportional Random Sampling. Pengambilan sampel secara proporsi dilakukan dengan mengambil subyek dari setiap strata atau setiap wilayah ditentukan seimbang dengan banyaknya subyek dalam masingmasing strata atau wilayah (Arikunto, 2006). Kemudian dilakukan tehnik Simple Random Sampling yaitu pengambilan sampel secara acak sederhana.

\section{Teknik Analisis Data}

Pengolahan data primer dilakukan menggunakan Program Komputer Statistik SPSS 20. Analisis deskriptif digunakan dalam penelitian ini untuk keperluan tahapan analisis/interpretasi data. Analisis deskriptif mengacu pada transformasi data-data mentah ke dalam suatu bentuk yang mudah dimengerti dan diterjemahkan. Pendeskripsian respons atau hasil observasi merupakan ciri khas dari bentuk pertama analisis. Perhitungan ratarata, distribusi frekuensi, dan distribusi persentase adalah bentuk yang paling umum dari peringkasan data (Wibisono, 2013, halaman 171). Dalam pengolahan data, statistik deskriptif digunakan. Sugiyono (2010:29) menyebutkan statistik deskriptif adalah statistik yang berfungsi untuk mendeskripsikan atau memberi gambaran terhadap obyek yang diteliti melalui data sampel atau populasi sebagaimana adanya, tanpa melakukan analisis dan membuat kesimpulan yang berlaku untuk umum.

\section{PEMBAHASAN \\ Sektor Ekonomi Kabupaten Kuningan \\ PDRB yang digunakan dalam} kajian ini adalah PDRB Kabupaten Kuningan tahun 2010-2014. PDRB tersebut telah mengalami perubahan klasifikasi dari PDRB Tahun Dasar 2000 ke PDRB Tahun Dasar 2010. Klasifikasi PDRB menurut lapangan usaha tahun dasar $2000(2000=100)$ menggunakan Klasifikasi Lapangan Usaha Indonesia 1990 (KLUI 1990) sedangkan pada PDRB tahun dasar $2010 \quad(2010=100) \quad$ menggunakan Klasisfikasi Baku Lapangan Usaha 2009 (KBLI 2009).

\section{SEKTOR DOMINAN}

\begin{tabular}{ccc}
\multicolumn{2}{c}{ Sektor-sektor } & dominan \\
merupakan sektor & kegiatan
\end{tabular}
ekonomi/lapangan usaha yang memberikan sumbangan (kontribusi) tertinggi terhadap PDRB kabupeten Kuningan, yang bersifat masif dan mencakup mata pencaharian penduduk dalam jumlah yang signifikan. Pertimbangan lain untuk sektor perekonomian dominan atau berpotensi dominan adalah gambaran potensi sumber daya alam, kemajuan teknologi, pemanfaatan potensi SDA dan peningkatan kualitas SDM dalam mengekplorasi potensi ekonomi daerah.

Dengan melihat besarnya kontribusi sektor pertanian terhadap PDRB Kabupaten Kuningan dan banyaknya penduduk yang mata pencahariannya di sektor pertanian maka dapat disimpulkan bahwa sektor pertanian merupakan sektor ekonomi yang dominan di Kabupaten Kuningan. 


\section{SEKTOR DOMINAN}

BERPOTENSI

Dengan melihat besarnya kontribusi sektor perdagangan besar dan eceran, reparasi mobil dan sepeda motor; sektor transportasi dan pegudangan; sektor konstruksi; sektor jasa pendidikan; dan sektor industri pengolahan terhadap PDRB Kabupaten Kuningan maka sektorsektor tersebut dikategorikan sebagai sektor yang berpotensi dominan di Kabupaten Kuningan.

\section{SEKTOR MARGINAL}

Sektor-sektor lainnya termasuk ke dalam sektor marginal dengan pertimbangan bahwa sektor-sektor tersebut memiliki kontribusi yang kecil terhadap PDRB Kabupaten Kuningan.

Analisis kecenderungan perubahan sektor ekonomi dominan di Kabupaten Kuningan

Sektor pertanian memberikan kontribusi paling tinggi terhadap PDRB Kabupaten Kuningan dengan rata-rata kontribusi sebesar $26.44 \%$ per tahun. Tetapi kecenderungannya dalam 5 tahun terakhir kontribusi sektor pertanian terus mengalami penurunan. Selain itu sektor pertanian juga merupakan salah satu sektor yang mengalami perlambatan pertumbuhan yaitu sebesar $-0,86$.

Posisi sektor pertanian sebagai sektor dominan dalam perekonomian Kabupaten Kuningan diperkirakan untuk beberapa tahun kedepan masih belum bergeser. Mengingat potensi sektor pertanian masih bisa dikembangkan dan diarahkan ke agrowisata.

Dari hasil analisis kontribusi/ peran masing-masing sektor dalam PDRB, sektor yang paling berpotensi untuk menjadi sektor dominan di
Kabupaten Kuningan adalah sektor perdagangan besar dan eceran, reparasi mobil dan sepeda motor.

Sektor perdagangan besar dan eceran, reparasi mobil dan motor ini juga mencakup usaha dibidang hotel, restoran, dan jasa-jasa. Diperkirakan sektor ini akan terus mengalami pertumbuhan seiring dengan pertumbuhan sektor ekonomi potensial di Kabupaten Kuningan. Pertumbuhan di sektor ini yang mencapai rata-rata $17.46 \%$ per tahun selama 5 tahun terakhir, juga diperkirakan erat kaitannya dengan adanya Kawasan BIJB-Aerocity. Dimana Kabupaten Kuningan diarahkan sebagai Pusat Kegiatan Lokal (PKL), dengan sarana dan prasarana pendukung minimal, serta diarahkan untuk menampung kegiatan sektor pertanian, wisata alam, agroindustri, dan daerah konservasi utama Taman Nasional Gunung Ciremai termasuk perlindungan sumber daya air. Sehingga sektor industri pariwisata alam (sumber air panas Gunung Ciremai) dan wisata budaya, industri kerajinan kayu, dan agrowisata diharapkan bisa berkembang pesat dan Kuningan menjadi tempat untuk destinasi wisata.

Faktor-Faktor Yang Menentukan Peningkatan Daya Beli Masyarakat di Kabupaten Kuningan

Berdasarkan data yang diperoleh dari BPS Kabupaten Kuningan dapat terlihat bahwa daya beli masyarakat Kabupaten Kuningan pada setiap tahunnya mengalami peningkatan kecuali pada tahun 2012 yang mengalami penurunan sebesar 0,68 dari tahun 2011. Namun jika kita lihat pada ketiga komponen yang membentuk IPM, indeks daya belilah yang termasuk komponen yang 
masih tergolong rendah dibandingkan dengan dua komponen lainnya. Berbagai upaya dilakukan untuk dapat mendongkrak daya beli tersebut namun belum membuahkan hasil yang optimal tren rata-rata peningkatannya sangat kecil setiap tahunnya.

Daya beli rendah diakibatkan oleh pendapatan yang rendah, yang pada akhirnya dapat mengakibatkan meningkatnya pengangguran dan menyebabkan pula terjadinya kemiskinan, dengan kemiskinan tersebut menyebabkan seseorang tidak dapat menjangkau pendidikan yang berkualitas serta membayar biaya pemeliharaan dan perawatan kesehatan. Dampak seperti inilah yang dinamakan dengan lingkaran setan, lingkaran setan inilah yang menyebabkan sulitnya pemerintah dalam mengurangi kemiskinan.

\section{Pelaku Usaha Sektor Perekonomian}

Responden yang diwawancarai seluruhnya sebanyak 303 orang yang merupakan pelaku usaha di 9 sektor ekonomi yang meliputi sektor dominan, berpotensi dominan, dan marginal.

Masing-masing pelaku usaha di 9 sektor ekonomi tersebut dilihat dari segi permodalan, pemasaran, tingkat persaingan usaha, dan omset penjualan.

\section{Hambatan dan Permasalahan yang Dihadapi Pelaku Usaha \\ Hambatan Permasalahan yang Dihadapi Pelaku Usaha Sektor Dominan dalam Mengembangkan Usahanya}

Berdasarkan hasil survey pada para pelaku usaha bahwa pada Sektor Pertanian, Kehutanan, dan Perikanan terdapat beberapa masalah terkait tenaga kerja diantaranya adanya kesulitan memperoleh tenaga kerja, rendahnya jenjang pendidikan formal tenaga kerja dan masalah lainnya. Permasalah lain yang dirasakan para responden yaitu mulai kesulitan mencari penerus usaha, terutama kegiatan pertanian; masalah permodalan diantaranya mengenai keterbatasan informasi mengenai bantuan dana atau permodalan, adanya kendala dalam pemenuhan syarat-syarat untuk pengajuan kredit usaha termasuk masih kecilnya modah usaha yang ditanamkan.

Selain itu, permasalahan dominan yang dirasakan pelaku usaha terkait pemasaran produk mereka yaitu adanya akses pasar yang kurang, tingkat persaingan yang dapat mempengaruhi keberlanjutan usaha dan masih kurangnya kegiatan promosi.

Disamping permasalahan terkait permodalan dan pemasaran, para pelaku usaha juga dihadapkan pada permasalahan terkait produksi. Masalah dalam produksi tersebut, terkait dengan masalah pengadaan bahan baku yang kadang sulit diperoleh dan permasalahan terkait penggunaan teknologi yang masih rendah. Padahal ketika teknologi sudah maksimal dimanfaatkan untuk kegiatan produksi mungkin akan memberikan kelebihan lain diantaranya dapat lebih mengefisiensikan waktu.

\begin{tabular}{lrr} 
Hambatan & Permasalahan yang \\
Dihadapi Pelaku Usaha & $\begin{array}{r}\text { Sektor } \\
\text { dalam }\end{array}$ \\
Berpotensi & Dominan & dalan \\
Mengembangkan Usahanya & \\
\multicolumn{2}{c}{ Pada sektor-sektor } & yang
\end{tabular} berpotensi dominan, permasalahan yang dihadapi terkait tenaga kerja yang dikeluhkan oleh para pelaku usaha, diantaranya adanya kesulitan memperoleh tenaga kerja, rendahnya jenjang pendidikan formal tenaga kerja dan masalah lainnya. 
Permasalahan lain yang dirasakan para responden yaitu mulai dari kesulitan mencari tenaga kerja yang menguasai keahlian pengelolaan keuangan terutama terkait pengelolaan modal; kesulitan mencari produk barang dagang; permasalahan adanya kenaikan Upah Minimum Regional (UMR) yang tentu saja berimbas pada kenaikan biaya gaji; permasalahan terkait permodalan diantaranya mengenai keterbatasan informasi mengenai bantuan dana atau permodalan, adanya kendala dalam pemenuhan syarat-syarat untuk pengajuan kredit usaha dan masih kurangnya modal usaha.

Selain itu, permasalahan dominan yang dirasakan pelaku usaha terkait pemasaran produk mereka yaitu adanya akses pasar yang kurang, tingkat persaingan yang dapat mempengaruhi keberlanjutan usaha.

Disamping permasalahan terkait tenaga kerja, permodalan dan pemasaran, para pelaku usaha juga dihadapkan pada permasalahan terkait produksi. Meskipun sektor ini tidak melakukan kegiatan pengolahan tetapi permasalahan produksi pada sektor ini termasuk kategori permasalahan dalam hal pengadaan barang dagang maupun sarana dan prasarana. Masalah dalam produksi tersebut, terkait dengan masalah pengadaan bahan baku (barang dagang) yang kadang sulit diperoleh, permasalahan terkait penggunaan teknologi yang masih rendah, sulitnya mencari tenaga kerja dan masalah terbatasnya keahlian tenaga kerja.

Hambatan Permasalahan yang Dihadapi Pelaku Usaha Sektor Marginal dalam Mengembangkan Usahanya

Permasalahan yang dihadapi pada sektor-sektor marginal hampir sama dengan permasalahan yang dihadapi pada sektor dominan dan berpotensi dominan seperti permasalahan pemasaran terkait akses pasar yang masih kurang masalah lain yang dikeluhkan oleh pelaku usaha terkait adanya persaingan usaha yang dirasakan dapat mempengaruhi keberlanjutan usaha.

Selain masalah pemasaran, pelaku usaha di sektor ini juga menghadapai masalah produksi terutama masalah terkait keahlian tenaga kerja dan permodalan. Keahlian tenaga kerja yang kurang maksimal dapat mempengaruhi kegiatan operasional, sebab jika tenaga kerja sudah memilki keahlian yang maksimal maka kegiatan operasional akan lebih optimal.

Sektor-Sektor Perekonomian yang Diprediksi akan Berdampak Signifikan pada Perbaikan Daya Beli Masyarakat Kabupaten Kuningan

Berikut sektor-sektor yang diprediksi akan berdampak signifikan pada perbaikan daya beli masyarakat Kabupaten Kuningan, (1) sektor pertanian merupakan sektor yang memiliki kontribusi paling besar terhadap PDRB Kabupaten Kuningan dengan rata-rata kontribusi mencapai $26,44 \%$ per tahun selama 5 tahun terakhir atau sekitar seperempat PDRB Kabupaten Kuningan diperoleh dari sektor pertanian. (2) sektor perdagangan besar dan eceran, reparasi mobil dan sepeda motor dengan rata-rata kontribusi terhadap PDRB mencapai $17.46 \%$ per tahun dalam 5 tahun terakhir, (3) sektor transportasi dan pergudangan telah memberikan kontribusi dengan rata-rata besar sumbangan $13.14 \%$ per tahun selama 5 tahun terakhir, (4) sektor konstruksi dengan rata-rata sumbangan $8.49 \%$ per tahun 
selama 5 tahun terakhir, (5) sektor jasa pendidikan memberikan kontribusi terhadap PDRB dengan rata-rata $7,26 \%$ per tahun selama 5 tahun terakhir, (6) sektor Industri Pengolahan terhadap PDRB Kabupaten Kuningan selama 5 tahun adalah $2,47 \%$. Angka ini relatif lebih kecil dibandingkan rata-rata kontribusi sektor lain. Namun demikian sektor Industri Pengolahan di Kabupaten Kuningan merupakan sektor yang cukup potensial dan harus terus dikembangkan. Sektor industri pengolahan juga harus diarahkan untuk mendorong pertumbuhan di sektor pertanian sebagai sektor dominan dalam perekonomian Kabupaten Kuningan.

Keenam sektor tersebut telah memberikan kontribusi yang relatif besar terhadap PDRB Kabupaten Kuningan. Dengan meningkatnya PDRB Kabupaten Kuningan maka diharapkan dapat memperbaiki daya beli masyarakat Kabupaten Kuningan.

\section{ANALISIS SKENARIO KEBIJAKAN DAN SASARAN PEMBANGUNAN EKONOMI SERTA PROGRMA-PROGRAM YANG DILAKUKAN \\ Arah Kebijakan dalam meningkatkan Minat Daya Beli Masyarakat \\ UMKM dan Koperasi}

Kebijakan di bidang UMKM dan koperasi di Kabupaten Kuningan yaitu meningkatkan daya saing UMKM dan Koperasi sehingga mampu tumbuh menjadi usaha yang berkelanjutan dengan skala yang lebih besar dalam rangka mendukung kemandirian perekonomian khususnya di Kabupaten Kuningan.

Strategi pembangunan yang akan dilaksanakan adalah : a. Peningkatan kualitas sumber daya manusia.

b. Peningkatan akses pembiayaan dan perluasan skema pembiayaan.

c. Peningkatan nilai tambah produk dan jangkauan pemasaran.

d. Penguatan kelembagaan usaha.

e. Peningkatan kemudahan, kepastian dan perlindungan usaha.

Kelima strategi tersebut mencakup beberapa upaya reformasi kebijakan dan pencapaian cepat (quick wins) sebagai berikut:

a. Peningkatan kualitas sumber daya manusia melalui (i) penguatan kebijakan kewirausahaan yang mencakup pola pengembangan kewirausahaan, penataan kurikulum kewirausahaan di lembaga pendidikan formal, serta perluasan dukungan khususnya bagi wirausaha berbasis teknologi (technopreneurs), dan (ii) peningkatan akses ke pelatihan, dan layanan usaha terpadu (quick wins).

b. Peningkatan akses pembiayaan dan perluasan skema pembiayaan melalui (i) pengembangan lembaga pembiayaan/bank UMKM dan koperasi, serta optimalisasi sumber pembiayaan non-bank, (ii) pengembangan credit rating bagi UMKM dan koperasi, (iii) peningkatan kapasitas koperasi sebagai pengelola sistem resi gudang (quick wins), dan (iv) advokasi pembiayaan bagi UMKM dan koperasi.

c. Peningkatan nilai tambah produk dan jangkauan pemasaran melalui (i) peningkatan kualitas dan diversifikasi produk berbasis rantai nilai dan keunggulan lokal, (ii) peningkatan penerapan standardisasi produk (Standar Nasional Indonesia/SNI, HaKI), dan sertifikasi (halal, keamanan 
pangan dan obat), (iii) penyediaan akses pasar bagi usaha mikro melalui revitalisasi pasar rakyat (quick wins), dan (iv) integrasi fasilitasi pemasaran dan sistem distribusi baik domestik maupun ekspor, yang didukung sistem informasi pasar, dan pengembangan trading house untuk produk-produk UMKM dan koperasi (quick wins).

d. Penguatan kelembagaan usaha melalui (i) kemitraan investasi berbasis keterkaitan usaha (backward-forward linkages) dan (ii) peningkatan peran koperasi dalam penguatan sistem bisnis pertanian dan perikanan, dan sentra industri kecil di kawasan industri.

e. Kemudahan, kepastian dan perlindungan usaha melalui (i) harmonisasi perizinan sektoral dan daerah, (ii) pengurangan jenis, biaya dan waktu pengurusan perizinan, (iii) penyusunan rancangan undang-undang tentang Perkoperasian dan pengembangan sistem registrasi UMKM secara online (quick wins), (iv) peningkatan efektivitas penegakan regulasi persaingan usaha yang sehat, dan (v) peningkatan sinergi dan kerja sama pemangku kepentingan (publik, swasta dan masyarakat) yang didukung sistem monitoring dan evaluasi terpadu yang berbasis data UMKM dan koperasi secara sektoral dan wilayah.

\section{Pariwisata}

Arah kebijakan yang akan ditempuh dalam pembangunan pariwisata di Kabupaten Kuningan :

a. Pembangunan Destinasi Pariwisata diarahkan untuk meningkatkan daya tarik daerah tujuan wisata sehingga berdaya saing di dalam negeri dan di luar negeri melalui: (i) fasilitasi pembangunan destinasi pariwisata nasional yang menjadi fokus pemasaran pariwisata dengan dalam penetapan kawasan peruntukan pariwisata dalam RTRW dan RRTR, site plan destinasi wisata beserta rancangan detail (detail design) kawasan destinasi wisata; (ii) bersama para pemangku kepentingan pariwisata membangun fasilitas umum di kawasan wisata; (iii) meningkatkan citra kepariwisataan; serta (iv) menata kelembagaan organisasi pengelola destinasi, destination management organisation (DMO). Jenis pariwisata yang akan dikembangkan khususnya untuk wisatawan manca negara mencakup: (i) wisata alam yang terdiri dari wisata bahari, wisata ekologi, dan wisata petualangan; (ii) wisata budaya yang terdiri dari wisata heritage dan religi, wisata kuliner dan belanja, dan wisata kota dan desa; dan (iii) wisata ciptaan yang terdiri dari wisata MICE \& Event, wisata olahraga, wisata kebugaran (wellness) berbasis budaya nusantara, serta wisata kawasan terpadu.

b. Pembangunan Industri Pariwisata diarahkan untuk meningkatkan partisipasi usaha lokal dalam industri pariwisata nasional serta meningkatkan keragaman dan daya saing produk / jasa pariwisata nasional di setiap destinasi pariwisata yang menjadi fokus pemasaran melalui: (i) pembinaan usaha pariwisata bagi masyarakat lokal, (ii) fasilitasi investasi usaha sektor pariwisata, serta (iii) fasilitasi pengembangan dan 
peningkatan jenjang keterampilan tenaga kerja lokal di bidang wisata.

c. Pembangunan Kelembagaan Pariwisata diarahkan untuk membangun sumber daya manusia pariwisata serta organisasi kepariwisataan nasional dengan strategi: (i) berkoordinasi dengan perguruan tinggi penyelenggara pendidikan sarjana di bidang kepariwisataan; (ii) meingkatkan kapasitas dan kualitas lembaga pendidikan kepariwisataan, memperluas jurusan dan peminatan, membangun sekolah pariwisata; serta (iii) turut serta menjaga kualitas pendidikan kepariwisataan yang diselenggarakan swasta.

d. Pemasaran pariwisata yang bertanggung jawab (Responsible marketing)

e. Peningkatan pelestarian nilai-nilai budaya

\section{Peningkatan Ekonomi Kreatif}

Arah kebijakan pembangunan ekonomi kreatif adalah memfasilitasi orang kreatif $(\mathrm{OK})$ di sepanjang rantai nilai yang dimulai dari tahap kreasi, produksi, distribusi, konsumsi, hingga konservasi.

a. Kreasi. Menyediakan fasilitas bagi OK untuk kegiatan kreasi seperti ruang kreatif, sarana kreatif, pada lingkup yang lebih luas mendorong terbangunnya klaster kreatif.

b. Produksi. Memfasilitasi OK memproduksi kreasinya dalam skala usaha yang layak secara ekonomi, dalam bantuk penetapan usaha baru (start-up), akses terhadap permodalan (pembiayaan), akses terhadap sarana/alat produksi, dan penyediaan sumber daya manusia / teknisi produksi dengan keterampilan yang tinggi. c. Distribusi. Memfasilitasi usaha baru ekonomi kreatif untuk mendapatkan akses ke pasar dan menjaga struktur pasar yang memudahkan pendatang baru.

d. Konsumsi. Memfasilitasi usaha baru ekonomi kreatif membangun pasar (market development) dan bila perlu membatu pembelajaran pasar (market learning).

e. Konservasi. Memfasilitasi terbangunnya repositories bagi produk-produk kreatif yang dimanfaatkan OK sebagai sumber inspirasi pada proses kreasi berikutnya.

Strategi pengembangan subsektor ekonomi kreatif dilaksanakan sesuai kebutuhan yaitu dengan:

a. Memperluas pasar produk kreatif Kuningan pasar baik di pasar ekspor maupun pasar domestik.

b. Memfasilitasi proses kreasi seperti pembangunan ruang kreasi, jaringan orang kreatif.

c. Memfasilitasi usaha kreatif sepanjang rantai produksi dengan menyediakan akses ke sumber permodalan atau pasokan SDM produksi, dan akses ke pasar.

d. Memfasilitasi penumbuhan usaha kreatif terutama bagi usaha pemula.

\section{Investasi}

Arah kebijakan investasi di Kabupaten Kuningan dengan penguatan investasi. Penguatan investasi adalah menciptakan iklim investasi dan iklim usaha yang lebih berdaya saing, baik di tingkat pusat maupun daerah, yang dapat meningkatkan efisiensi proses perijinan, meningkatkan kepastian berinvestasi dan berusaha di Kabupaten Kuningan, serta mendorong persaingan usaha yang lebih sehat dan berkeadilan. 
Adapun strategi yang ditempuh:

a. Peningkatan kepastian hukum terkait investasi dan usaha melalui peningkatan iklim investasi dan Iklim usaha.

b. Penyederhanaan prosedur perijinan investasi dan usaha di pusat dan daerah

c. Pengembangan layanan investasi yang memberikan kemudahan, kepastian, dan transparansi proses perijinan bagi investor dan pengusaha, melalui: Optimalisasi penyelenggaraan PTSP di daerah, yang antara lain dilakukan dengan mendorong pelimpahan wewenang perijinan investasi dari instansi teknisi dan kepala daerah kepada PTSP.

\section{Pembangunan Desa dan Kawasan} Perdesaan

Arah kebijakan dalam pembangunan desa dan kawasan perdesaan di Kabupaten Kuningan sebagai berikut :

a. Mengurangi kemiskinan dan kerentanan ekonomi di kawasan perdesaan

b. Memenuhi SPM khususnya di desa-desa tertinggal dan perbatasan

c. Meningkatkan keberdayaan masyarakat kawasan perdesaan

d. Mewujudkan desa berkelanjutan, yang berbasis pada potensi sumber daya sosial budaya lokal dan daerah, serta

e. Membangun keterkaitan desa kota melalui pengembangan kegiatan perekonomian hulu-hilir dan industrialisasi kawasan perdesaan khususnya di desa-desa yang telah berkembang dan mandiri yang terkait dengan industri di pusatpusat pertumbuhan terdekat.

\section{Perdagangan dan Jasa}

Arah kebijakan dalam pembangunan perdagangan dan jasa di Kabupaten Kuningan sebagai berikut :

a. Program Perlindungan Konsumen dan Pengamanan Perdagangan

b. Pembinaan dan Pengembangan Pasar Daerah dan Desa

c. Peningkatan Efisiensi Perdagangan Dalam Negeri

d. Meningkatnya investasi daerah yang ramah lingkungan

e. Peningkatan dan Pengembangan Ekspor

f. Program Peningkatan Kerjasama Perdagangan Internasional

g. Terwujudnya pembangunan agribisnis terpadu

\section{Pertanian}

Arah Kebijakan dalam pembangunan pertanian di Kabupaten Kuningan sebagai berikut:

a. Meningkatkan nilai tambah dan perbaikan infrastruktur pertanian sehingga sektor pertanian mempunyai daya saing.

b. Melakukan spesifikasi komoditas, pengembangan usaha pada produk unggulan tataran lokal dan nasional yaitu komoditas pangan dan hortikultura serta hasil perkebunan.

c. Peningkatan kualitas SDM pelaku pertanian

d. Adanya perlindungan harga pada tingkat hilir

e. Optimalisasi peran lembaga/paguyuban yang mewadahi petani

\section{Sumber Daya Manusia}

Arah kebijakan pembangunan dalam sumber daya manusia di Kabupaten Kuningan sebagai berikut:

a. Adanya pendidikan tinggi bidang pariwisata

b. Adanya keseimbangan antara pendidikan umum, keagamaan, pembentukan karakter dan kepribadian, disiplin, memiliki etos kerja dan jiwa kewirausahaan 
c. Meningkatnya kualitas, aksesibilitas dan relevansi pendidikan masyarakat

d. Sumber daya manusia Kabupaten Kuningan sudah setara dengan kabupaten tetangga serta sudah mampu mengembangkan potensi ekonomi lokal yang ada

e. Meningkatnya kualitas tenaga kerja produktif

f. Kerukunan antar umat beragama terjaga dan masyarakat menerapkan nilai-nilai keagamaan dalam kehidupan keseharian

g. Terbentuknya masyarakat yang berbudaya, memiliki etos kerja, disiplin, jiwa kewirausahaan serta aktif berpartisipasi dalam pembangunan daerah

\section{Daya Saing}

Arah kebijakan dalam pembangunan daya saing di Kabupaten Kuningan sebagai berikut:

a. Meningkatkan seluruh aspek daya saing seperti infrastruktur fisik

b. Meningkatkan seluruh aspek daya saing tetapi tetap mempertahankan ciri tradisional, dan budaya Kuningan

c. Pelayanan akomodasi yang prima serta birokrasi yang sederhana dengan ciri masyarakat modern dan menjadikan ciri keseharian serta masyarakat religius berlandaskan iman dan takwa

\section{Sasaran dalam Meningkatkan Daya Beli Masyarakat UMKM dan Koperasi}

Upaya peningkatan daya saing UMKM dan koperasi di Kabupaten Kuningan dapat mewujudkan sasaransasaran sebagai berikut:

a. Meningkatnya kontribusi UMKM dan koperasi dalam perekonomian yang ditunjukkan oleh pertumbuhan nilai PDB UMKM dan koperasi, yang didukung peningkatan kontribusi UMKM dan koperasi dalam penciptaan lapangan kerja, dan investasi.

b. Meningkatnya daya saing UMKM, yang ditunjukkan oleh pertumbuhan produktivitas UMKM, serta didukung peningkatan akses permodalan dan penerapan standarisasi mutu dan sertifikasi produk.

c. Meningkatnya usaha baru yang ditunjukkan oleh jumlah pertambahan wirausaha baru yang dikontribusikan dari program nasional dan daerah.

d. Meningkatnya kinerja kelembagaan dan usaha koperasi, yang ditunjukkan oleh peningkatan partisipasi anggota koperasi dalam permodalan, pertumbuhan jumlah anggota koperasi, dan pertumbuhan volume usaha koperasi.

\section{Pariwisata}

Sasaran pembangunan pariwisata adalah sebagai berikut:

a. Tersusun dan terwujudnya pemantapan kebijakan nasional pengembangan destinasi pariwisata.

b. Meningkatkan pengembangan kebijakan destinasi pariwisata.

c. Meningkatkan kebijakan pengembangan destinasi pariwisata utama berkelas dunia.

d. Meningkatnya daya saing usaha pariwisata nasional.

e. Meningkatnya jumlah kunjungan wisatawan nusantara.

f. Tersusunnya standard dan sistem akreditasi produk dan usaha pariwisata.

g. Terlaksananya pengimplementasian standarisasi, akreditasi dan sertifikasi produk dan usaha pariwisata 


\section{Peningkatan Ekonomi Kreatif}

Sasaran dalam pembangunan ekonomi kreatif adalah sebagai berikut:

a. Meningkatnya PDRB Kabupaten Kuningan

b. Banyaknya informasi lowongan kerja sehingga dapat menyerap tenaga kerja bagi masyarakat di Kabupaten Kuningan

c. Meningkatnya jumlah usaha di berbagai sektor baik industri perumahan dan lain-lain di Kabupaten Kuningan

d. Meningkatkan PAD Kabupaten Kuningan dari berbagai aspek pariwisata dan lain-lain.

\section{Investasi}

Sasaran pembangunan investasi di Kabupaten Kuningan adalah:

a. Menurunnya waktu pemrosesan perijinan investasi maksimal 15 hari kerja per jenis perizinan berdasarkan peraturan yang ada.

b. Menurunnya waktu dan jumlah prosedur untuk memulai usaha (starting a business) menjadi 7 hari dan 5 prosedur sesuai dengan SOP yang ada.

c. Tersedianya informasi berupa pemetaan wilayah bagi investor yang akan berinvestasi.

Pembangunan Desa dan Kawasan Perdesaan

Sasaran pembangunan desa dan kawasan perdesaan di Kabupaten Kuningan adalah:

a. Mengurangi jumlah desa tertinggal yang ada disetiap kecamatan.

b. Meningkatkan jumlah desa mandiri yang ada disetiap kecamatan.

c. Mewujudkan penghidupan yang berkelanjutan bagi masyarakat miskin dan rentan di desa.

d. Terpenuhinya standar pelayanan minimum. e. Meningkatnya keberdayaan masyarakat pedesaan.

f. Terwujudnya tata kelola perdesaan yang baik.

g. Terwujudnya kemandirian pangan dan pengelolaan SDA-LH yang berkelanjutan dengan memanfaatkan inovasi dan teknologi tepat guna di kawasan perdesaan, dan

h. Terwujudnya keterkaitan kota-desa melalui pengembangan ekonomi lokal kawasan perdesaan

Program-Program

Meningkatkan Daya Beli

Masyarakat

UMKM dan Koperasi

Program-Program UMKM dan

Koperasi yaitu:

1) Program Penciptaan Iklim Usaha Usaha Kecil Menengah Yang Kondusif

a. Penyusunan kebijakan tentang Usaha Kecil Menengah;

b. Penyederhanaan regulasi terkait dengan UMKM dan Koperasi;

c. Fasilitasi pengembangan UMKM dan Koperasi;

d. Pendirian unit penanganan pengaduan;

e. Pengembangan jaringan infrastruktur Usaha Kecil Menengah;

f. Fasilitasi Koperasi, Usaha Mikro, Kecil dan Menengah Berbasis Kelompok dan Kluster;

g. Monitoring, evaluasi dan pelaporan.

2) Program Pengembangan Sistem Pendukung Usaha Bagi UMKM

a. Koordinasi penggunaan dana Pemerintah bagi UMKM;

b. Koordinasi penggunaan dana CSR bagi pengembangan UMKM dan pemberdayaan masyarakat; 
c. Pengembangan sarana pemasaran produk UMKM;

d. Peningkatan kerjasama jaringan antar lembaga;

e. Pengembangan sistem informasi bagi UMKM;

f. Fasilitasi bantuan modal bagi UMKM dengan bunga ringan;

g. Pengembangan usaha keuangan mikro (micro finance);

h. Pemantauan pengelolaan penggunaan dana pemerintah bagi UMKM;

i. Penyelenggaraan promosi produk UMKM;

j. Monitoring, evaluasi dan pelaporan.

3) Program Peningkatan Kualitas Kelembagaan Koperasi

a. Sosialisasi prinsip prinsip pemahaman perkoperasian;

b. Pelatihan manajemen Koperasi berbasis kelompok atau kluster;

c. Peningkatan dan pengembangan jaringan kerjasama usaha Koperasi;

d. Pembinaan, pengawasan dan penghargaan Koperasi berprestasi;

e. Penyebaran model-model pola pengembangan Koperasi;

f. Monitoring, evaluasi dan pelaporan.

4) Program Pengembangan

Kewirausahaan dan Keunggulan

Kompetitif UMKM

a. Penyelengaraan pelatihan kewirausahaan;

b. Fasilitasi promosi produkproduk unggulan kompetitif usaha kecil menengah;

c. Monitoring, evaluasi dan pelaporan.

\section{Pariwisata}

Program-program pariwisata antara lain:
1) Program
Pemasaran Pariwisata

a. Kegiatan analisa pasar untuk promosi dan pemasaran objek pariwisata

b. Kegiatan pemanfaatan peningkatan informasi dalam pemasaran pariwisata

c. Kegiatan pengembangan jaringan kerjasama promosi pariwisata

d. Kegiatan koordinasi dengan sektor pendukung pariwisata

e. Kegiatan pelaksanaan promosi pariwisata nusantara antara di dalam dan diluar negeri

f. Kegiatan pemantauan dan evaluasi pelaksanaan program pengembangan pemasaran pariwisata.

g. Kegiatan pengembangan statistik Kepariwisataan

h. Kegiatan pelatihan Pemandu Wisata

2) Program Pengembangan Destinasi Pariwisata

a. Kegiatan pengembangan objek pariwisata unggulan

b. Kegiatan peningkatan pembangunan sarana dan prasarana pariwisata

c. Kegiatan pengembangan jenis dan paket wisata unggulan

d. Kegiatan pelaksanaan koordinasi pembangunan objek pariwisata dengan Lembaga/Dunia Usaha

e. Kegiatan pemantauan dan evatuasi pelaksanaan program pengembangan Destinasi Pariwisata

f. Kegiatan Pengembangan daerah tujuan wisata

g. Kegiatan pengembangan, sosialisasi dan penerapan serta pengawasan standarisasi.

3) Program Pengembangan Kemitraan 
a. Kegiatan pengembangan dan penguatan, dan informasi dan database

b. Kegiatan pengembangan dan penguatan Litbang, Kebudayaan dan Pariwisata

c. Kegiatan pengembangan SDM di bidang kebudayaan dan pariwisata bekerjasama dengan lembaga lain

d. Kegiatan pelaksanaan koordinasi pembanguaan kemitraan Pariwisata

e. Kegiatan pemantauan dan evaluasi pelaksanaan program peningkatan kemitraan

f. Kegiatan pengembangan sumber daya manusia dan profesionalisme bidang Pariwisata

g. Kegiatan peningkatan peran serta masyarakat dalam pengembangan kemitraan pariwisata

h. Kegiatan monitoring, evaluasi dan pelaporan realisasi Pelaksanaan Program dan Kegiatan

\section{Pembangunan Desa dan Kawasan Perdesaan}

Program-program dalam pembangunan desa dan kawasan perdesaan di Kabupaten Kuningan sebagai berikut :

1) Peningkatan kualitas sarana dan prasarana kawasan perdesaan

2) Peningkatan kehidupan sosial dan ekonomi kawasan perdesaan

3) Peningkatan kualitas SDM kawasan perdesaan

4) Konservasi dan peningkatan kualitas lingkungan kawasan perdesaan.

\section{PENUTUP}

Berdasarkan analisis rata-rata kontribusi/ peran sektor-sektor dalam
PDRB Kabupaten Kuningan dapat disimpulkan bahwa :

1. Sektor Perekonomian di Kabupaten Kuningan terdiri dari:

a. Sektor dominan dalam perekonomian Kabupaten Kuningan adalah sektor pertanian

b. Sektor yang berpotensi dominan meliputi 4 sektor, yaitu :

- sektor perdagangan besar dan eceran, reparasi mobil dan sepeda motor

- sektor transportasi dan pergudangan

- sektor konstruksi

- sektor jasa pendidikan

c. Sektor marginal meliputi 12 sektor, yaitu :

- Pertambangan dan penggalian

- Industri pengolahan

- Pengadaan listrik dan gas

- Pengadaan air, pengolahan sampah, limbah dan daur ulang

- Penyediaan akomodasi dan makan minum

- Informasi dan komunikasi

- Jasa keuangan dan asuransi

- Real Estate

- Jasa perusahaan

- Administrasi pemerintah, pertahanan dan jaminan sosial wajib

- Jasa kesehatan dan kegiatan sosial

- Jasa lainnya

2. Rendahnya daya beli masyarakat Kabupaten Kuningan disebabkan masih rendahnya pendapatan perkapita masyarakat Kuningan. Sementara itu kecenderungannya harga-harga secara umum (tingkat inflasi) semakin meningkat. Kondisi ini akan semakin menekan daya beli masyarakat Kabupaten Kuningan menjadi semakin 
rendah. Faktor-faktor yang menyebabkan rendahnya pendapatan masyarakat Kuningan, secara langsung akan menyebabkan rendahnya daya beli masyarakat di Kabupaten Kuningan. Adapun faktor yang menyebabkan rendahnya pendapatan perkapita Masyarakat Kuningan masih rendah, diantaranya :

a. Masih sedikitnya pelaku usaha di sektor ekonomi dominan (pertanian)

b. Masih banyaknya hambatan dan permasalahan yang dihadapi oleh sektor ekonomi dominan dalam mengembangkan usahanya, diantaranya :

- Kualitas SDM dan kelembagaan pertanian masih lemah

- Produksi, produktivitas dan mutu tanaman pangan, hortikultura, perkebunan dan peternakan belum optimal

- Rendahnya pemanfaatan teknologi dalam peningkatan produksi dan pengolahan hasil pertanian dalam rangka agribisnis

- Terbatasnya sarana dan prasarana pertanian

c. Masih kecilnya kontribusi/peran sektor-sektor yang berpotensi dominan terhadap PDRB Kabupaten Kuningan.

3. Rancangan kebijakan pembangunan untuk meningkatkan daya beli masyarakat di Kabupaten Kuningan, melalui peningkatan konstribusi sektor dominan dan sektor berpotensi dominan.

\section{DAFTAR PUSTAKA}

Abdul Hakim, 2004. Ekonomi Pembangunan. Edisi Pertama,
Cetakan Kedua. Yogyakarta: Ekonisia, Kampus Fakultas Ekonomi UII.

Atih Rohaeti Dariah, 2006. Reorientasi Strategi Pembangunan dalam rangka Meningkatkan Daya Beli Masyarakat di Jawa Barat, Jurnal Volume XXII No. 4 Oktober - Desember : 428-443

Badan Pusat Statistik Kabupaten Kuningan (2015). Produk Domestik Regional Kabupaten Kuningan Menurut Lapangan Usaha Tahun 2010-2014.

Chenery, Hollis dan Moises Syrquin, 1975. Patterns of Development. Oxford University Press, London.

Dewi Fatmasari, 2015. Ekonomi Pembangunan. Nurjati Press, IAIN Syekh Nurjati Cirebon.

Lita Jonatas, 2013. Analisis Sektor Unggulan Perekonomian Kabupaten Kuningan. Tesis, Universitas Kuningan

Joseph E. Stiglitz. 2000. Challenges in the Analysis of the Role of Institution in Economic Development, http://www.dse.de/ef/instn/stiglitz. htm

Kuznets, 1996. Modern Economic Growth, Yale University Press.

Lewis, W.A. 1954. Economic Development with Unlimited Supplies of Labor In Chenery and Srinivasan (Editors). Handbook of Development Economics. Science Publisher B.V., Amsterdam.

Mankiw. 2000. Macroeconomics. Fourth edition. Worth Publisher

Mudrajat Kuncoro, 2006. Ekonomi Pembangunan: Teori, Masalah dan Kebijakan. UPP AMP YKPN Yogyakarta.

Nu'man Harits, 2006. Mendongkrak Daya Beli Masyarakat melalui Transfer "Knowledge" Berbasis Teknologi (sebuah model 
konseptual). Jurnal Volume XXII

No. 3 Juli - September 2006 : 355

Paul Krugmann, Robin Wells. 2006.

Economics. Worth Publisher

Suparmoko, dan Maria R.

Suparmoko, 2000. Pokok-Pokok

Ekonomika, Yogyakarta: Penerbit BPFE.

Suryana, 2000. Ekonomi

Pembangunan: Problematika dan

Pendekatan. Edisi Pertama,

Jakarta: Salemba Empat.

Sumitro Djojohadikusumo, 2000.

Ekonomi Pembangunan, Jakarta:

Pustaka Ekonomi.

Sadono Sukirno, 2006, Ekonomi

Pembangunan Proses masalah dan

Dasar Kebijakan,cetakan ketiga,

Penerbit Kencana, Jakarta.

Sjafrizal. 2008. Ekonomi Regional

Teori dan Aplikasi, Penerbit

Baduose Media: Sumatra Barat.

Tambunan Tulus, 2001.

Perekonomian Indonesia Teori

dan Temuan Empiris.Jakarta:

Ghalia Indonesia.

UNDP. 1996. Laporan Human

Development Report, New York,

UNDP. 2001. Laporan

Pembangunan Manusia, Publikasi

Bersama BPS, Bapppenas dan

UNDP Indonesia 